\title{
Language, Gender and Women Development in South Africa
}

\author{
Dr. Elliot Mthembeni Mncwango \\ University of Zululand - kwaDlangeza Campus, Private Bag x1001 Kwa-Dlangezwa - South Africa, 3886 \\ Email: MncwangoE@unizulu.ac.za \\ Ms. Monica Dudu Luvuno \\ University of Zululand - kwaDlangeza Campus, Private Bag x1001 Kwa-Dlangezwa - South Africa, 3886 \\ Email: luvunom@unizulu.ac.za
}

Doi:10.5901/jesr.2015.v5n2p245

\section{Abstract}

The issues discussed in this article are about language discrimination, struggle for gender equality and women development including in education, household income and unemployment. The article also discusses gender and sexism in language and how this ought to change, as well as the development of women in areas of education and household income. Examples of gender discrimination and sexism have been drawn, largely, from isiZulu, but generalisations are made, as isiZulu is not the only language that the article identifies as discriminatory and sexist. The objectives were to show how isiZulu differentiates between men and women in Zulu society, and to examine whether it is still sexist, despite the acceptance of the South African Constitution of 1996, which is against unfair discrimination of women by society. The study relied on published literature and the statistics pre- and post-apartheid. This was in order to compare and contrast the status of women during the periods in question. It found that more female-headed households, relative to male-headed households, had no income in 2001 than in 1996. On education it found, among other things, that the drop in the enrolment of girls exceeded that of boys.

Keywords: Sexism; language discrimination; gender equality

\section{Introduction}

The article addresses issues of language, gender and women development in South Africa, and the strides that the country has made since the advent of democracy. It sought to show how language differentiates between men and women in Zulu society, and to examine whether isiZulu language is still sexist despite the acceptance of the South African Constitution of 1996, which is against unfair discrimination of women by society. The sexist language that is used which differentiates women from men does not seem to give women the opportunity to see themselves as independent and intelligent human beings.

The article also aimed to find out the effect of societal stereotypes in developing women as a separate species to men. It sought to compare and contrast the roles of men and women, using the country's patriarchal history as its backdrop, and then tried to gauge the level of success, or lack thereof, the country has achieved in closing the gap between gender groups. In so doing, the article explored the roles of women and men in the household and in society. It drew, largely, on isizulu language, with some references made to sexism and the society's expectations of women, and roles of women within society, and whether these have evolved over time since democracy. This is all supported by literature written during the post-apartheid era, which has recorded the progress made by the gender groups in question, supported by statistics.

The study relied on published literature and the statistics pre- and post-apartheid. This was in order to compare and contrast the status of women during the periods in question. Furthermore, the article discusses studies which had investigated the general wellbeing of South Africans, with the aim of ascertaining whether vulnerable groups (including women) have gained anything in the latest two census years.

\section{Women as Inferior to Men}

In most African traditional rural societies women have been considered inadequate in performing tasks that are traditionally performed by men and they have been given lower status than men. Cultural practices designed and applied 
by men have favoured them over women. For example, it is considered normal for an African man to enter into a polygamous marriage, but it is taboo for a woman in almost all South African populations. African societies in particular, have extended such practices even to the way in which derogatory language is used when referring to women. Positive qualities such as wisdom, courage and good behavior are normally attributed to men.

A society's attitude largely expresses its belief system through its use of language. In Zulu custom, for instance, if a boy acts intelligently, it is usually said that he has inherited that from his father (ufuze uyise),but if the boy acts foolishly or misbehaves, a finger is pointed at the mother as being the one who is ill-mannered (Moyo, 2012) and the one from whom he has inherited foolishness (ufuze ekhaya konini), and not from the father. Zulu women are not given the equal status to men - they are considered secondary to men and are treated as their subordinates. The concern is that such attitude projects women negatively and it is against what is stated by section 9 of the South African Constitution:

1. Equality includes the full and equal enjoyment of all rights and freedoms. To promote the achievement of equality, legislative and other measures designed to protect or advance persons or categories of persons, disadvantaged by unfair discrimination may be taken.

2. No person may unfairly discriminate directly or indirectly against anyone.

This means that every individual, including women, has the right not to be unfairly discriminated against by any other person, including men. It is, however, notable that the South African Constitution purports to protect citizens from others who might wish to discriminate against them. What is observed is that in South Africa instances of language discrimination, and other forms of discrimination abound among members of the same society, where instances of language discrimination are a daily experience.

It is noted, however, that women have made good contributions in our society as well. In fact, it has been argued that women are often more responsible than men in Zulu families. This is attested by Polly (1988) when he states that 'if a man, as the head of the family, does not provide for his family, he knows that the mother will. But, if women do not care enough for their children, they know their children risk neglect.' In social conflicts arising from the state's inability to guard its citizens against poverty, for example, many women become the sole support of their families because male breadwinners are unable or unwilling to provide (Isike and Uzodike, 2011: 225). It is on rare cases that the mother does not take the responsibility of raising deserted children even if it means she does so single-handedly.

\subsection{Within the household}

In traditional Zulu society, as in many other traditional African societies, the father is the head of the family and he has absolute authority and control over the wife and children. The father sets rules and punishes whoever does not obey his rules. Women hold less powerful roles and lack formalised control. Soul Magazine (2004) explains that women's submission is a dilemma which stems from the very foundations of Black culture. African tradition demands that a woman should always be on her husband's side, although she cannot sit and share at the same table with him. African women submit to their 'despotic husbands' otherwise they are 'tortured beyond endurance' and their lives become hard if they fail to submit to their partners (Isike and Uzodike 2011:227). Actually, respect is the glue that holds relationships together. It is not simply respect for the individual, but also respect for the integrity of the relationship and family; being able to walk with each other and not for one to feel superior over the other (Cowdery, et al. 2009).

\subsection{In society}

From time immemorial, the Zulu traditional men in rural areas would, once each month, hold traditional meetings, normally under a specially selected huge tree, outside induna's kraal to discuss important societal matters. Only men and not women would be allowed to form part of those meetings. Men had the belief that African culture does not permit women to be active in the public space or to be equal with men. Zulu men argued that in Zulu culture women are inferior to men and never contest with men when it comes to issues of politics and that politics is culturally a man's domain. If a woman had something to say in that specific meeting, she would only be allowed to tell her husband, who would then speak on her behalf to induna's men, which is called ibandla in isizulu. A woman could only attend the meeting if she came to testify with the induna's permission, otherwise she would not even be allowed to say a word. Many Zulu men feel that being dominant in their relations with females is part of being umnumzane, 'real manhood' in isizulu (Isike and Uzodike 2011:228). But this is in conflict with section 16 of the South African Constitution, which states that everyone has a right to freedom of expression. This means that women too have freedom of expression and hatred based on gender displayed by men or hate speech is uncalled for and against the law. 
De Kadt (2003) argues that changing the names and surnames of women after they have married serves as linguistic sexism, directed only towards women. Even though she can still be called by her own surname within the family premises, it is the woman, in most African societies, who changes her surname after the marriage, not the man. Fathers and grandfathers are the name-givers and it is the father's surname which is retained by the children, and this custom is passed from generation to generation in a Zulu family (Ngubane and Thabethe, 2013). Consequently, most men think that just because they were born males, they are somehow, not only superior to women, but also own them.

According to Romaine (1994: 102), early research also revealed that 'the size and volume of women's brains were once measured and when they were found to be smaller than men's, this was taken as a sign of generic inferiority for women.'

In Zulu custom a woman is often regarded as a child even if she is the eldest at home. A woman is never older than a man because that would mean that she is wiser and maybe superior to him, which is unacceptable to Zulu men.

In the workplace, women colleagues are expected to pour tea, organise lunch while men are expected to automatically assume leadership roles, pay for business lunch, sit in the front seat of the car or handle serious management issues (Isike and Uzodike 2011: 233). For women to be regarded as intelligent and capable in Zulu society, they have to imitate men, particularly in the language that they use. For example, this has resulted in many women denying their own personalities and inclinations in order to be listened to and be taken seriously. Some women change even their favourite activities, such as baking or sewing, since these are viewed as too feminine, and adopt men's interests, such as sports and politics, to gain men's attention and recognition.

Although the Constitution of South Africa is against practices that make women vulnerable to harmful discriminatory cultural practices, and stresses equality, recent studies show that such practices have not changed significantly, particularly in Zulu society. The general observation is that the traditional rural Zulu society should redress the existing social imbalances and do away with linguistic discrimination of women. Small changes that can be made in how isizulu language is used, could contribute to further changes in attitudes towards women as well.

\section{Linguistic Custom of Respect}

In Zulu culture, a newly - married woman is called umakoti, and she is not allowed to use certain words, but she is expected to avoid them, be it in the presence of the members of her new family, or in their absence. She has to use the 'language of respect', known as isihlonipho sabafazi (Finlayson, 2002). The umakoti is expected to respect her in-laws; treat them with respect and deference. For example, if the name of her husband's grandfather's or of anyone of the elders in the family, be he or she one of the living or the deceased, is Sigebengu (a criminal), umakoti could use another word, like inswelaboya (similar to 'a criminal' in meaning). She is expected to use or coin a particular hlonipha word, and say maybe utsotsi, which is a synonym of the word isigebengu (Chaka, 2000).

If umakoti deliberately ignores this rule after she has been taught by the elders in her new family, she is regarded as disrespectful and she is told to go back to her father's house to be taught respect by her parents. Of course, she would have been taught about this by her parents before marriage, and also by the elders in the new family. There are mechanisms in place to deal with cases that may arise within the family structures. Therefore, the decision to send umakoti to her father's house is the last resort, after everything else has failed.

In modern times the role of umakoti is still perceived as a form of slavery and isolation. She is not free to act according to her wishes due to restrictive social rules and norms allotted to her. These rules create a picture of an 'ideal girl' or 'ideal woman' which, on the contrary, restrict the rights and privileges that the women are supposed to have around a Zulu home (Keshabanada, 2012).

\section{Sexism in Isizulu Language}

A rich Nguni language, isizulu, is not without sexism, as demonstrated above. There are many examples where the language favours males over females, and tends to place the latter in inferior position. Some isizulu words that are associated with women are derogatory and they do not have corresponding equivalents in reference to men, despite the fact that a situation to which they refer may apply to both genders. For example, an unmarried old man is called impohlo (a bachelor), and this word does not have much negative connotation to men - it simply means a man who has never married, whose age group have married. On the other hand, an unmarried woman is referred to as uzenda zamshiya (someone who was left over when other women were chosen by men), or umjendevu (an old woman who has never been married), which carries a similar connotation. Similarly, a divorced woman is called umabuy' emendweni (the one 
who returned to her father's house after a failed marriage), but there is no specific name given to a divorced man in isizulu, except to say 'akundoda yalutho -wehlulwa ukuphatha umuzi'(He is a useless man - he failed to run his household). In fact, within this context, men who have divorced, are not even considered for community leadership positions for, how can they lead the community if their house is not in order?

Societal division of labour on the basis of gender still prevails in Zulu homes. Women are confined to their roles as housewives, and the male tasks are considered special; more valued than female tasks (Chabaya et al. 2009: 46). In other instances, of course, their tasks are a bit more physically challenging. The point here is that women are too soft, and need protection from their husbands - who should, after all, fend for their families.

The same standards do not apply equally to both genders, either in the traditions of Zulu society or in the way in which language is used. According to Buthelezi (2006), even the language of reporting in isizulu newspapers continues to reinforce traditional gender stereotypes and inequalities. Half of the population in the world is women, but culturally, women are still made to feel lower than men; considered the second sex; occupy a secondary position; earn lower wages than men; have lower literacy rates; have limited access to social services; have greater difficulty obtaining employment and are regarded as appendages to men. These obstacles make them a minority group despite being in the majority (Chabaya et al. 2009: 241; Isike and Uzodike, 2011:225; Romaine, 1994: 103; Keshabanada, 2012: 1). The point that this article is making is that, despite the acceptance of the South African Constitution of 1996, isizulu society and its language remain sexist in nature.

In Reddy and Kadt's view (2006) to be 'gendered' as a woman means to be available for men's manipulation and to be 'gendered' as a man means to be born into social and cultural privilege. According to Isike and Uzodike (2011) Zulu culture is 'deeply patriarchal, with women seen as subhuman, commodified and subordinated.'

Religion also does not allow women to lead free life. Muslim women, for example, put burkhas on their face once they are married, and not men. Hindu religion also puts many restrictions on women. In India, the high level of gender inequality is shocking and astonishing even nowadays. For example, modern medical technology had made it possible for parents all over India to abort a female foetus, and this goes unnoticed; lower social status is attached to a woman not having a son; derogatory terms like 'nipatrika' are used to refer to such a woman, but not to a man of similar status (Mahadevappa, 2012).

Herbert (1992: 335) states that language and words can be good or bad and discriminatory depending on the people using them. In isizulu, a woman is called uyindoda, (a man), if she has done something worthwhile. The term uyindoda (You are a man.) is sometimes also used on men who have performed outstandingly, or who have surpassed ordinary human beings. This example, suggests that only men can be achievers of heroic deeds, unlike women, normally.

However, if a man has a tendency of doing the wrong things all the time or misbehaves, he would be reduced to the level of a woman, simply called umfazi (a woman). Zulu men do not want to listen or respect their wives' opinions even if they are sound because a real man should not be told by a woman (umfazi) what to do. If a man does that he is viewed as weak and not man enough (Udonswa wumfazi ngekhala), implying that the man is a coward and he dances to his wife's tune. Non-assertiveness in a woman is an expected attribute of an umakoti, whereas stubbornness is viewed as being strong and a good characteristic of a Zulu man - Singamadoda thina, angekesitshelwe ngabafazi ukuthi senzeni (We are men, we are not going to be told by women what to do).

\section{Language Discrimination}

Fromkin and Rodman (1978: 277) argue that words with positive connotations are used when referring to men whereas words or expressions with negative connotations are used when referring to women. In Zulu society, the word isoka (a playboy), for example, is used for a man who has more than one sexual partner, but if a heterosexual woman has more than one partner, she is given derogatory names, some of which are insulting. The same situation is described and judged differently by the same society when a man is involved. What is socially acceptable in a man is socially unacceptable and is frowned upon in a woman. If a man gossips it is said that he speaks softly and it is viewed as a normal behaviour. However, when the same is done by a woman, she is particularly said to be gossiping (uyahleba) (Herbert, 1992). This means that it is proper for a man to gossip, whereas for a woman, it is not.

A woman is called umdlezane, which means a woman who has recently given birth. She is regarded as an outcast by society on account of her biological and physical condition. In olden days a man was not allowed to enter the room where there was umdlezane according to the Zulu custom, even if she was his wife until a certain period of time was over. If a wife does not conceive, she is said to be barren and she is called inyumba (a derogatory name for an infertile 
woman). This is unfortunate, because in some instances, the woman is fertile but for some unknown factors, she cannot bear children. Very seldom do members of the society, and at times, family members, want to find out whether there is a condition in the husband that leads to the couple not having children.

In theory, men and women in Zulu society are equal but in practice, equality in Zulu society is non-existent. There are observable differences between the ways isizulu language is used in women as opposed to men, as exemplified above. Vulgar and swearing is about women. For example, if a person misbehaves, he is likened to his or her mother. This kind of language denigrates women in their role as mothers. The Bill of Rights, as a cornerstone of democracy of South Africa, in section 10 and 12 enshrines the rights of all people in the country and affirms the democratic values of human dignity, equality and freedom: Everyone has inherent dignity and the right to have their dignity respected and protected.

\section{The Development of Women Post 1994}

With the above-mentioned gender imbalances, coupled with racism that has been part of South Africa's history since the pre-colonial era, it is not easy to place women's struggle for gender equality (Walker 1990). However, the post-apartheid era has seen more and more struggles by different sectors of the South African communities, especially the Black communities, who suffered severely during the pre-democratic era.

Studies, for example Oranje (2003) have investigated the general wellbeing of South Africans, aiming to ascertain whether vulnerable groups (including women) have gained anything in the latest two census years. Among others is Oranje's study on attainment of knowledge and income. On education, the study found that almost $28 \%$ of South Africa's population was illiterate in 1996. Although the absolute position of women, in terms of illiteracy improved between 1996 and 2001, their relative position worsened in that:

(a) The rate of the reduction in the absolute number of illiterate females was half as rapid as that of males;

(b) Women constituted an even larger proportion of the illiterate population in 2001 than in 1996; and that

(c) There were more illiterate females relative to males in 2001 than in 1996.

The study found that out of the total number of about 8 million children that were enrolled in primary school in 1996, the figure had dropped by $8,9 \%$ to 7.5 million in 2001, and that there were fewer girls in primary school than there were in 1996, both in absolute terms and relative to boys given that:

(a) The drop in the enrolment of girls exceeded that of boys;

(b) Girls represented a smaller share of total primary school enrolments in 2001 than in 1996;

(c) The decrease in gross enrolment ration (GER) of girls exceeded that of boys; and that

(d) Primary school gender parity deteriorated during this time.

Education is one of the best tools that can be used to change the status of underprivileged women for the better. There are many factors which could account for the school drop-out rates, as discussed. However, an attempt could be made to keep women in school, in order to change their way of like, as some of the gender inequalities that are so high could be addressed through education.

On household income, the 1996 Census found that 14, 28\% of all households in South Africa had no income. Within five years this figure had increased to $23,21 \%$. Women also lost ground relative to men in that:

(a) The rate at which female-households joined the zero income group exceeded that of male-headed households; and that

(b) More female-headed households, relative to male-headed households, had no income in 2001 than in 1996.

It is a reality that our past in South Africa has seen women in junior employment positions, and they have, by and large, been paid meager salaries, in relation to men's salaries - although this does not by any means suggest that men were treated with kid gloves by the colonial and apartheid regimes. Black women, like Black men, were not represented in government until 1994, when a change happened. Their participation in business and other sectors showed little or, in some instances, no representation at all. There is progress currently in South Africa, in that the ruling party is calling for fifty per cent (50\%) representation at all spheres of government. Other non-governmental sectors also are doing something about women representation. These efforts, it is hoped, will change the status of female - households for the better.

On unemployment, the 2001 census found that 4.6 million people were deemed unemployed in 1996 with almost 2 million more joining them in 2001. What was of concern was that:

(a) the rate of increase in the absolute number of female unemployed surpassed that of men;

(b) Within the unemployed group women were increasing their majority; and 
(c) More women than men were unemployed in 2001 than in 1996.

South Africa is from the past wherein certain jobs were for males only. These included: truck driving; construction work; post and telecommunications; bricklaying, etc. This practice hampered the progress that women could make in order to be able to fend for their families, especially in female-headed households, and also put women under the control of men, in that they were unemployable in certain companies - which made them dependent upon their husbands even though they were capable of contributing towards the daily expenses of the household. Changes in this practice have seen many companies employ women drivers; there are many women technicians; there are women taxi drivers, etc. Therefore, strides have been made to improve the rate of unemployment among women, but more still needs to be done.

\section{Concluding Reflections}

The article has discussed language discrimination and sexism, with examples drawn from isizulu, not as the only language found to be discriminatory, but with some evidence that it is. It was found that in Zulu custom, for instance, if a boy acts intelligently, it is usually said that he has inherited that from his father (ufuze uyise), but if the boy acts foolishly or misbehaves, a finger is pointed at the mother as being the one who is ill-mannered (Moyo, 2012) and the one from whom he has inherited foolishness (ufuze ekhaya konini), and not from the father.

Gender imbalances that have been part of South Africa's history since the pre-colonial era have been discussed, as well as the struggle for gender equality. Gender groups should have mutual respect - it is not simply respect for the individual, but also respect for the integrity of the relationship and family; being able to walk with each other and not for one to feel superior over the other (Cowdery, et al. 2009).

The article has also discussed women development in education as well as on household income, since gender imbalances affected women not only in one area, but economically and educationally as well. It found that more femaleheaded households, relative to male-headed households, had no income in 2001 than in 1996. On education it also found that the drop in the enrolment of girls exceeded that of boys.

The above-mentioned points paint a rather bleak picture of our struggle for gender equality and educational and economic development of women post-apartheid. More could still be done by different language groups to address gender imbalances, and also by women themselves, to cure the declining figures of girls in primary schools. It is through education that the affected gender group (women) could fully understand gender imbalances and, perhaps, fight a winning battle.

\section{References}

Buthelezi, T. (2006). 16 Days of Activism and Gender Stereotypes in llanga, Isolezwe and UmAfrica newspapers. Southern African Linguists and Applied Language Studies Journal, 24(4): 497-509.

Chabaya, O., Rembe, S. \& Wadesango, N. (2009). The Persistence of Gender Inequality in Zimbabwe: Factors that Impede the Advancement of Women into Leadership Positions in Primary Schools. South African Journal of Education. Vol, 29:235-251.

Chaka, C. (2000). Shaking, Subverting and Sinking Foundations: isiXhosa in South Africa. Toward a Socially (Ir)responsible Applied Linguistics. Paper read at the conference for the South African Association of Language Teaching I(SAALT) held at the University of Free State in Bloemfontein, 4-6 July.

De Kadt, E. (2003). Language and Gender. In Southern African Linguistics and Language Studies. (Book Review).

Finlayson, R. (2002). Women Language of Respect Isihlonipho Sabafazi. In Mesthrie R. (ed), Language in South Africa, Cambridge: Cambridge University Press. Fromkin, V. \& Rodman, R. (1993). An Introduction to Language. New York: Holt Rinchart and Winston Inc. $3^{\text {rd }}$ Edition.

Herbert, R. K. (1992). Language and Society. The Theory and Practice of Sociolinguistics. Johannesburg: Witwatersrand.

Hoosain, I. (2012). Muslim Women of West Bengal: An Enquiry into their Minority Status. IOSR Journal of Humanities and Social Sciences. Vol, 4(3) pp. 14-21.

Isike, C. \& Uzodike, U. O. (2011). Managing women in politics: Recent trends in Kwazulu-Natal. Development Southern Africa. Vol. 28, no.2. Routledge, Taylor and French Group.

Lumby, J. \& Azoala, C. (2011). Women Principals in Small Schools in South Africa. Australian Journal of Education, Vol. 55(1), 73-85.

Mahadevappa, T. C. (2012). Gender Bias and Social Justice. IOSR Journal of Humanities and Social Sciences Vol. 4, Isuue 2, p42-44.

Moyo, T. (2012). Language Use and Gender Positioning among the Swazi. LWATI: Journal of Contemporary Research, Vol, 142-158.

Mutekwe, E. \& Modiba, M. (2012). Girls Career Choices as a Product of a Gendered School Curriculum: the Zimbabwean Example. South African Journal of Education. Vol, 32:279-292.

Ngubane, S. \& Thabethe, N. (2013). Shifts and continuities in Zulu personal naming practices. Literator 34(1), Art. \#431, 7 pages. http://dx.doi.org/10.4102/lit.v34i1.431

Reddy, V. \& Kadt, E. (2006). Thinking about Language and Gender: a South African Perspective. Southern African Linguistics and Applied Studies, 24(4): 417423.

Romaine, S. (1994). Language in Society. An Introduction to Sociolinguistics. New York. Oxford University Press.

Soul Magazine. (2004). Cultural Views on Women's Submission-righting the Wrongs. January, 2004.

South Africa. Constitution of the Republic of South Africa. Act no. 108 of 1996.

Sri. Keshabanada Borah 2012. Human Rights, Health, Gender and Sexuality. IOSR Journal of Humanities and Social Sciences (JHSS) ISSN: 2279 - 0845. Vol.5, Issue 3, p44-47. 